\title{
The Effect of The Thrombolytic Treatment on Inflammatory Markers in Male Patients with Pulmonary Thromboembolism
}

\author{
Pulmoner Tromboembolisi Olan Erkek Hastalarda Trombolitik Tedavinin \\ İnflamatuvar Belirteçler Üzerindeki Etkisi \\ Hüseyin Oren ${ }^{1}$, Ayhan Coşgun ${ }^{2}$ \\ ${ }^{1}$ Department of Cardiology, Cardiology Specialist, Ankara City Hospital, Ankara, Turkey \\ ${ }^{2}$ Department of Cardiology, Cardiology Specialist, Dr. Nafiz Korez Sincan State Hospital, Ankara, Turkey
}

Yazışma Adresi / Correspondence:
Hüseyin Oren
Department of Cardiology, Cardiology Specialist, Ankara City Hospital, Ankara, Turkey.
T: +90 532 574 $3630 \quad$ E-mail : husoren@ @hotmail.com
Geliş Tarihi / Received : 18.10.2020 Kabul Tarihi / Accepte: 03.05.2021
Orcid :
Hüseyin Oren: https://orcid.org/0000-0003-0128-014X
Ayhan Coşgun: https://orcid.org/0000-0001-5147-161X
(Sakarya Tip Dergisi / Sakarya Med J 2021, 11(3):593-600 ) DoI: 10.31832/smj.812253

\footnotetext{
Öz

Objective Neutrophil to lymphocyte (NLR) and platelet to lymphocyte (PLR) ratios play an important role in monitoring the progression of the disease and determining the course of the disease in patients with acute pulmonary thromboembolism (APTE). This study aims to determine whether there is any change in NLR, PLR, and C-reactive protein (CRP) in patients with APTE receiving thrombolytic therapy.

Materials Sixty-five male patients with shortness of breath, chest pain, and palpitations, who were diagnosed with APTE by examinations and thorax computed tomography and Methods angiography, and who were hospitalized and given thrombolytic therapy were included in the study. The files of these patients were scanned retrospectively, and NLR and PLR and CRP values were recorded 1-2 days before and 1-4 days after thrombolytic therapy. Then, it was checked whether there was a difference between pre-treatment and post-treatment values.

Results NLR, PLR, CRP and systolic pulmonary artery pressure values decreased statistically significantly in patients with APTE by thrombolytic therapy.

Conclusion NLR, PLR, CRP and sPAP values were found to be statistically significantly decreased with thrombolytic treatment.

Keywords Acute Pulmonary Thromboembolism; Inflammation; C-Reactive Protein
}

Abstract

Amac Nötrofil-lenfosit (NLR) ve trombosit-lenfosit (PLR) oranlart, akut pulmoner tromboembolizm (APTE) olan hastalarda, hastalğın ilerlemesinin izlenmesinde ve hastaliğın seyrinin belirlenmesinde önemli bir rol oynamaktadır. Bu çalıșma, trombolitik tedavi alan APTE'li hastalarda NLR, PLR ve C-reaktif protein (CRP) 'de herhangi bir değişiklik olup olmadığın belirlemeyi amaçlamıştrr.

Gereç ve Muayeneler ve toraks bilgisayarl tomografi anjiyografisi ile APTE tanısı konulan, nefes darliğı, göğüs ağrısı ve çarpintı nedeniyle hastaneye yatırllp trombolitik tedavi verilen 65 erkek hasta, Yöntemle çalısmaya dahil edildi. Bu hastaların dosyaları geriye dönük olarak tarandı ve trombolitik tedaviden 1-2 gün önce ve 1-4 gün sonra NLR, PLR ve CRP değerleri kaydedildi. Daha sonra tedavi öncesi ve sonrast değerler arastnda fark olup olmadı̆̆ı kontrol edildi.

Bulgular Trombolitik tedavi ile APTE'li hastalarda NLR, PLR, CRP ve sistolik pulmoner arter basınç değerleri istatistiksel olarak anlamlı azald.

Sonuç Trombolitik tedavi ile NLR, PLR, CRP ve SPAP değerlerinin istatistiksel olarak anlamlı derecede azaldı̆̆ı bulundu. 


\section{INTRODUCTION}

Acute pulmonary thromboembolism (APTE) is a life-threatening condition. Both treatment options and mortality are directly proportional to the severity of the disease. APTE is a serious disease with high mortality despite advanced treatment methods. The incidence of APTE is estimated to be 23-69 per 100.000 people annually in the USA. ${ }^{1}$ PTE alone causes 300,000 deaths each year in Europe. ${ }^{2}$ Short-term mortality varies between $2 \%$ and 95 $\%$ depending on the severity of the disease. ${ }^{3}$

Thrombus formation is caused by abnormalities in the blood flow, vessel wall, and blood contents. Inflammation causes endothelial damage, increases procoagulant factors, inhibits natural anticoagulant pathways, and fibrinolytic activity. ${ }^{4}$ Kurtipek et al. found a relationship between NLR and PLR values and endothelial dysfunction in patients with APTE. They thought that endothelial dysfunction might play a role in the development of cardiovascular events in patients with APTE. ${ }^{5}$ NLR and PLR have been associated with many inflammatory diseases. Few studies have investigated the effect of NLR and PLR on short-term mortality rates in patients with APTE. ${ }^{6,78}$ NLR and PLR can be affected by many factors and their predictive capacity may therefore be limited by these factors. Serious infections and hematological diseases are some of these factors. NLR and PLR play an important role in monitoring the progression of the disease and in managing the treatment of patients with APTE. It has been found that NLR and PLR are a better indicator of inflammation than white blood cell count. ${ }^{8}$

Recently, PLR has been considered as a new marker of systemic inflammation. ${ }^{9}$ It has been found that PLR is more useful than evaluating lymphocytes or thrombocytes separately in evaluating some cardiovascular diseases. ${ }^{10}$ As well known, CRP is an acute-phase reactant that increases in many inflammatory diseases. The effect of thrombolytic therapy on NLR, PLR, and CRP in patients with APTE has not been investigated in studies conducted so far. This study aims to investigate the effect of this treatment on NLR, PLR, and CRP levels in patients with APTE who received thrombolytic therapy.

\section{MATERIALS and METHODS}

Study Population: This study was conducted retrospectively on the records of patients who were diagnosed with APTE in the Ankara City Hospital by Chest Diseases Department between February 2019 and June 2020 and received thrombolytic therapy for this reason. Sixty-five male patients who were admitted to the emergency department with complaints of sudden onset of shortness of breath, chest pain, and palpitations and were diagnosed with definite APTE by examinations and thorax computed tomography angiography, and who were hospitalized by the chest diseases clinic and given thrombolytic therapy were included in the study. In the radiology clinic, imaging was performed with multi-slice spiral Computorised Tomography (CT) using the pulmonary embolism protocol. APTE was diagnosed with the detection of a complete or partial filling defect in the main pulmonary artery or branches. This study is a cross-sectional and descriptive type of clinical study performed in our hospital.

When selecting patients, only thoracic CT angiography results were taken into care. Troponin and D-dimer were not taken into consideration in patient selection since they were not studied in some patients and our study was conducted retrospectively.

Exclusion criteria were: Patients with pneumonia, systemic infections, hematological malignancies, acute myocardial infarction, COPD patients, oncologic patients, connective tissue patients, patients with severe liver and kidney disease, a history of primary pulmonary hypertension or secondary pulmonary hypertension.

The files of these patients were scanned retrospectively, and their demographic and clinical characteristics, treatments, laboratory and imaging findings, and patients' results were 
recorded. Then, NLR and PLR and CRP values were measured 1-2 days before and 1-4 days after treatment in male patients who received thrombolytic therapy.

Inflammatory markers differ in males and females on the basis of disease, age ranges and gender. So the reason why we only included men in the study is to make the results more homogeneous and reach reliable results in a narrower area. ${ }^{31}$

\section{Thrombolytic Treatment}

In patients diagnosed with pulmonary thromboembolism, $100 \mathrm{mg}$ recombinant-Tissue Plasminogen Activator (r-TPA) was administered as an intravenous infusion in 2 hours.

\section{Transthoracic Echocardiorgaphy}

The Continuous Wave Doppler of the tricuspid valve failure (TR) tracing was used to measure the pressure difference between the right ventricle and right atrium. In the Bernoulli formula, the value obtained by the CW over TR was replaced and the pressure difference between the right ventricle and the right atrium was calculated. The value obtained from the Bernoulli formula is traditionally calculated by the addition of right atrial pressure to calculate systolic pulmonary arterial pressure.

\section{Statistical analysis}

In this study, the 20.0 version of SPSS was used. The Kolmogorov-Smirnov test was used to understand whether the data were normally distributed. The transformation was applied to nonparametric data. The Paired Samples t-test was used to understand whether there was a difference between the two groups for continuous variables and the Chi-square test for categorical data. Spearman or Pearson correlation analyzes were conducted to find out whether there is any correlation between the data. Continuous variables are defined as mean \pm SD (standard deviation), while categorical variables are defined as percentage values. $\mathrm{P}$-value $<0.05$ was considered statistically signifi- cant.

\section{CT Imaging}

In the radiology clinic, imaging was performed using the pulmonary embolism protocol with multi-slice spiral CT. Acute PTE was diagnosed with the detection of a complete or partial filling defect in the main pulmonary artery or branches.

\section{Ethical Approval}

All procedures performed in studies involving human participants were following the ethical standards of the Turkey Research Committee and with the 1964 Helsinki Declaration and its later comparable ethical standards. The present study permit was obtained from the Ethical Committee of Ankara City Hospital (No: E1-20-940, Date:16/07/2020). Informed written consent was obtained from each of the patients participating in the study.

\section{RESULTS}

The sociodemographic characteristics and baseline clinical findings of the patients included in the study are shown in Table 1.

After thrombolytic therapy, NLR [3.98 \pm 1.72 v.s $2.49 \pm 1.09]$ $[\mathrm{P}<0.0001], \mathrm{PLR}[143.5 \pm 72.2$ v.s $117.96 \pm 66.1][\mathrm{P}=0.031]$, CRP [38.74 \pm 9.98 v.s $16.56 \pm 4.01][\mathrm{P}<0.0001]$, and sPAP [67.3 \pm 14.7 v.s $47.8 \pm 12.2][\mathrm{P}<0.0001]$,values were found to be statistically significantly lower than before (Table 2 ). Before thrombolytic treatment, there was a moderate positive correlation between SPAP and NLR values $[R=0.533$, $\mathrm{P}<0.0001$ ], and a weak positive correlation between sPAP and PLR $[R=0.422, \mathrm{P}=0004]$, sPAP and CRP $[\mathrm{R}=0.377$, $\mathrm{P}=0.0024$ ] values. After thrombolytic therapy, there was a weak positive correlation between SPAP and NLR $[\mathrm{R}=0.325, \mathrm{P}=0.0093]$, sPAP and PLR values $[\mathrm{R}=0.258$, $\mathrm{P}=0.044]$, but no correlation was found between sPAP and CRP values $[\mathrm{R}=0.114, \mathrm{P}=0.383]$ (Table 3 ). 
Table 1: Sociodemographic characteristics and basal clinical findings of the male patients with acute pulmonary thromboembolism who have taken thrombolytic treatment.

\begin{tabular}{|c|c|}
\hline Variables & Study population $(\mathrm{N}=65)$ \\
\hline Age & $75.6 \pm 6.6$ \\
\hline Male $\%$ & 100 \\
\hline AST & $40.5 \pm 4.5$ \\
\hline BMI, kg/m2 & $30.3 \pm 2.6$ \\
\hline Basal heart rate, beats/min & $95.6 \pm 3.7$ \\
\hline Systolic Blood Pressure, $\mathrm{mmHg}$ & $143.6 \pm 11.5$ \\
\hline Diastolic Blood Pressure, mmHg & $86.5 \pm 7.6$ \\
\hline LV mass, gram & $184.3 \pm 20.1$ \\
\hline sPAP, mm Hg & $67.3 \pm 14.7$ \\
\hline Glucose, $\mathrm{mg} / \mathrm{dl}$ & $102.5 \pm 9.5$ \\
\hline $\mathrm{TSH}, \mathrm{mU} / \mathrm{l}$ & $2.1 \pm 0.56$ \\
\hline Total cholesterol, mg/dl & $284.7 \pm 42.7$ \\
\hline Triglyceride, mg/dl & $254.7 \pm 18.7$ \\
\hline LDL cholesterol, mg/dl & $185.4 \pm 23.6$ \\
\hline HDL cholesterol, mg/dl & $44.2 \pm 4.4$ \\
\hline Sodium, mEq/l & $140.4 \pm 1.6$ \\
\hline Calcium, mg/dl & $9.2 \pm 0.3$ \\
\hline Potassium, mEq/l & $4.5 \pm 0.2$ \\
\hline Magnesium, mg/dl & $2.3 \pm 0.1$ \\
\hline Creatinin, $\mathrm{mg} / \mathrm{dl}$ & $1.02 \pm 0.2$ \\
\hline
\end{tabular}

Abbr: AST; Aspartate Aminotransferase, BMI; Body mass index, LV; Left Ventricle, sPAP; systolic pulmonary artery pressure, TSH; Thyroid Stimulating Hormone, LDL; Low-Density Lipoprotein, HDL; High-Density Lipoprotein.
Table 2: Some variables of patients before and after thrombolytic treatment in male patients with acute pulmonary thromboembolism.

\begin{tabular}{|l|c|c|c|c|}
\hline Variables & $\begin{array}{c}\text { Before } \\
\text { thrombolysis }\end{array}$ & $\begin{array}{c}\text { After } \\
\text { Thrombolysis }\end{array}$ & T-value & P-value \\
\hline WBC & $9754.8 \pm 3058.1$ & $8260.8 \pm 2887.8$ & 2.791 & 0.006 \\
\hline Neutrophil & $6962.2 \pm 2441.8$ & $5142.2 \pm 2007.9$ & 4.532 & $<0.0001$ \\
\hline Lymphocyte & $1974.1 \pm 795.53$ & $2318.4 \pm 951.9$ & 2.193 & 0.030 \\
\hline Hemoglobin & $13.1 \pm 1.79$ & $12.88 \pm 1.59$ & 0.597 & 0.550 \\
\hline RDW & $13.78 \pm 1.67$ & $13.74 \pm 1.52$ & 0.133 & 0.883 \\
\hline Platelet & $282628 \pm 73261$ & $271982 \pm 75452$ & 0.795 & 0.423 \\
\hline MPV & $7.14 \pm 2.18$ & $7.17 \pm 2.21$ & 0.076 & 0.934 \\
\hline CRP & $38.74 \pm 9.98$ & $16.56 \pm 4.01$ & 16.236 & $<0.0001$ \\
\hline NLR & $3.98 \pm 1.72$ & $2.49 \pm 1.09$ & 5.767 & $<0.0001$ \\
\hline PLR & $143.5 \pm 72.2$ & $117.96 \pm 66.1$ & 2.111 & 0.031 \\
\hline sPAP & $67.3 \pm 14.7$ & $47.8 \pm 12.2$ & 12.703 & $<0.0001$ \\
\hline
\end{tabular}

Abbr: WBC; White Blood Cell Count, RDW; Redcell Distribution Width, MPV; Mean Platelet Volume, CRP; C-Reactive Protein, NLR; Neutrophil to Lymphocyte ratio, PLR; Platelet to Lymphocyte Ratio, sPAP; systolic pulmonary artery pressure. Paired samples' $t$ test were used here to compare the means.

Table 3: The correlation between SPAP and NLR, PLR and CRP values before and after the thrombolytic treatment in male patients with acute pulmonary thromboembolism.

Before the thrombolysis

\begin{tabular}{|l|c|c|c|c|}
\hline Variable 1 & Variable 2 & R-value & P-value & Correlation \\
\hline sPAP & NLR & 0.533 & $<0.0001$ & Moderate Positive \\
\hline sPAP & PLR & 0.422 & 0.0004 & Weak Positive \\
\hline sPAP & CRP & 0.377 & 0.0024 & Weak Positive \\
\hline After the thrombolysis \\
\hline sPAP & NLR & 0.325 & 0.0093 & Weak Positive \\
\hline sPAP & PLR & 0.258 & 0.044 & Weak Positive \\
\hline sPAP & CRP & 0.114 & 0.383 & No Correlation \\
\hline Abr
\end{tabular}

Abbr: sPAP; Systolic pulmonary artery pressure, CRP; C-Reactive Protein, NLR; Neutrophil to Lymphocyte ratio, PLR; Platelet to Lymphocyte Ratio

\section{DISCUSSION}

In our study, the P-value was found to be $<0.0001$ when compared with the CRP value before and after the thrombolytic therapy. A statistically significant difference was found when comparing the NLR value before and after thrombolytic therapy $(\mathrm{P}<0.0001)$. When the pre-treatment PLR value was compared with the post-treatment PLR value, a statistically significant difference was found $(\mathrm{P}=0.03)$. Contrary to the studies in the literature, we can say that our study is the first study showing the reducing 
effect of thrombolytic therapy on inflammation markers such as CRP, NLR, and PLR. However, whether this effect affects short or long term mortality in patients with APTE should be investigated with further studies.

In our study, although there was a moderate positive correlation between SPAP and NLR before thrombolytic therapy, this correlation was weak after treatment. This finding suggested that thrombolytic therapy decreased NLR and sPAP values and the relationship between them could be weakened by thrombolytic therapy. The reason for the weakening of this relationship may be due to the significant decrease in both values. Although the correlation coefficient between SPAP and PLR decreased, the relationship level did not change. However, while there was a weak relationship between sPAP and CRP before thrombolytic therapy, this relationship became insignificant after treatment. This finding suggested that thrombolytic therapy was associated with a significant decrease in sPAP and CRP values.

Inflammatory markers differ in males and females on the basis of disease, age ranges and gender. So the reason why we only included men in the study is to make the results more homogeneous and reach reliable results in a narrower area. ${ }^{31}$

Thrombolytic therapy appears to decrease sPAP statistically significantly (Table $2, \mathrm{P}<0.0001$ ). The decrease in sPAP is thought to be associated with significant reductions in morbidity and mortality in patients with APTE. Longterm cohort studies are needed to quantitatively determine the reduction in morbidity and mortality. ${ }^{32}$

Acute pulmonary thromboembolism (APTE) is a life-threatening condition. Both treatment options and mortality are directly proportional to the severity of the disease. Acute pulmonary embolism is a serious disease with high mortality despite advanced treatment methods. The incidence of PE is estimated to be 23-69 per 100,000 people annually in the USA.1. PE alone causes 300,000 deaths each year in Europe. ${ }^{2}$ Short-term mortality varies between $2 \%$ and $95 \%$ depending on the severity of the disease. ${ }^{3}$ Patients with a suspected or definite diagnosis of shock or prolonged arterial hypotension are considered to be at high risk. Patients without this clinical condition are regarded as non-high-risk patients. ${ }^{11}$ Anticoagulation is recommended for low-risk patients and thrombolytic therapy or embolectomy for high-risk patients. There is no definite option in terms of thrombolytic therapy or anticoagulant therapy in moderate-risk patients. Meyer et al. found that fibrinolytic therapy in moderate-risk patients prevented hemodynamic impairment but increased the risk of bleeding and stroke. ${ }^{12}$ Sharifi et al. found that lowdose tissue plasminogen activator was safe and effective in moderate-risk PTE and reduced pulmonary artery pressure for more than 6 months. ${ }^{13}$

APTE is the third most common vascular disease seen after acute coronary syndrome and cerebrovascular diseases. Despite the new diagnosis and treatment methods, the mortality rate of $\mathrm{PE}$ is as high as $15-25 \% .^{14,15}$ As in other atherothrombotic diseases, inflammation has an important place in the pathophysiology of PTE. The effect of thrombolytic therapy on long-term survival has not yet been determined.

NLR shows the balance between neutrophils and lymphocytes. It has been proposed as a marker for systemic inflammation. ${ }^{16}$ High NLR is caused by increased neutrophil or decreased lymphocyte count. Increased cortisol levels in response to stress may cause such a response. Inflammation can lead to the production of neutrophils and apoptosis of lymphocytes. Jo et al. Found that systemic inflammatory response syndrome criteria were more common in patients with PTE who died within the first 30 days of hospitalization. ${ }^{17}$ This study revealed the effect of systemic inflammation on short-term mortality in patients with PTE. The results of this study support the hypothesis that NLR is an important risk predictor of 30-day mortality. By 
evaluating the NLR, clinicians can distinguish high-risk patients from medium and low-risk patients. Based on the calculated NLR, the treatment plan can be changed to reduce short-term mortality.

In acute stress situations such as acute coronary syndrome and APTE, lymphopenia can also be seen in these conditions due to the release of corticosteroids and increased apoptosis. ${ }^{18,19}$ Platelets also play a key role in inflammation and thrombosis. ${ }^{9}$ Therefore, hematological markers, especially NLR and PLR, can be used as an inflammation marker besides being biochemical markers. Karataş et al. Found in their study that NLR and PLR at admission were predictors of short and long-term mortality, independent of age, pulmonary embolism severity index (PESI) score, systolic blood pressure, and sPAP ${ }^{20}$.

Kurtipek et al. found that there was a relationship between NLR and PLR values and endothelial dysfunction in patients with PTE. They thought that endothelial dysfunction might play a role in the development of cardiovascular events in patients with PTE. ${ }^{5}$ NLR and PLR have been associated with many inflammatory diseases. These markers are increasingly used as prognostic markers of many cardiovascular diseases and cancers. Few studies have investigated the effect of NLR and PLR on short-term mortality rates in patients with PTE. ${ }^{6,7}$. NLR and PLR can be affected by many factors and their predictive capacity may therefore be limited by these factors. Serious infections and hematological diseases are some of these factors. NLR and PLR play an important role in monitoring the progression of the disease and managing the treatment of patients with PTE. ${ }^{8}$

Recently, PLR has been considered as a new marker of systemic inflammation. ${ }^{9}$ It has been found that PLR is more useful than evaluating lymphocytes or thrombocytes separately in evaluating some cardiovascular diseases. ${ }^{10}$ nary arterial and venous wall inflammation; In this process, leukocyte migration occurs to the vessel wall and as a result, an increase occurs in inflammatory mediators, including CRP.6 Increased PLR and NLR levels indicate a more severe form of the disease and a higher level of inflammation. Studies have shown that NLR and PLR measurements are important in many cardiovascular diseases. $^{21,22}$

The NLR is a useful prognostic marker in acute coronary syndromes, ${ }^{23,24}$ malignancies, ${ }^{25}$ contrast nephropathy,26 heart failure ${ }^{27}$ and pulmonary hypertension. ${ }^{28}$

In a study done by Soylu et al., it was found that NLR was associated with the severity and prognosis of the disease in patients with APTE. Since it is easy to measure in emergency departments, it is also a useful marker in risk stratification of the disease. ${ }^{29}$ Özcan Çetin et al. found a relationship between increased PLR rates in patients with APTE and in-hospital mortality and long-term adverse events in their study. ${ }^{30}$

\section{Study Limitations}

This study has some limitations. This is a retrospective study conducted in a single center with a limited sample. Troponin and D-dimer values are important predictors for PTE. These markers were not included in our study; because in more than half of the patients receiving thrombolytics, these markers had not been measured. It is necessary to conduct studies with more cases to obtain better information.

\section{Conflict Of Interes}

The authors declare that they have no conflict of interest. There is no source(s) of support in the form of grants, equipment, and drugs. All expenses are paid by the authors. 


\section{Ethical Approval}

All procedures performed in studies involving human participants were following the ethical standards of the Turkey Research Committee and with the 1964 Helsinki Declaration and its later comparable ethical standards. The present study permit was obtained from the Ethical Committee of Ankara City Hospital (No: E1-20940, Date:16/07/2020). Informed written consent was obtained from each of the patients participating in the study. 
Sakarya Med J 2021;11(3):593-600

ORENȘ et alk., Inflammatory Markers and Thrombolytic Treatment

\section{References}

1. Silverstein MD, Heit JA, Mohr DN, Petterson TM, O'Fallon WM, Melton LJ., III Trends in the incidence of deep vein thrombosis and pulmonary embolism: a 25-year population-based study. Arch Intern Med. 1998;158:585-93.).

2. Cohen AT, Agnelli G, Anderson FA, Arcelus JI, Bergqvist D, Brecht JG, et al. (VTE) in Europe. The number of VTE events and associated morbidity and mortality. Thromb Haemost. 2007;98:756-64.

3. Aujesky D, Obrosky DS, Stone RA, Auble TE, Perrier A, Cornuz J, et al. A prediction rule to identify low-risk patients with pulmonary embolism. Arch Intern Med. 2006;166:169-75.

4. Aksu K, Donmez A, Keser G. Inflammation-induced thrombosis: mechanisms, disease associations, and management. Curr Pharm Des. 2012;18:1478-93.

5. Kurtipek E, Buyukterzi Z, Buyukterzi M, Alpaydin MS, Erdem SS. Endothelial dysfunction in patients with pulmonary thromboembolism: neutrophil to lymphocyte ratio and platelet to lymphocyte ratio. Clin Respir J. 2015. doi:10.1111/cri.12308.

6. Cavus UY, Yildirim S, Sonmez E, Ertan C, Ozeke O. Prognostic value of neutrophil/lymphocyte ratio in patients with pulmonary embolism. Turk J Med Sci. 2014;44:50-5.

7. Akgullu C, Omurlu IK, Eryilmaz U, Avcil M, Dagtekin E, Akdeniz M, et al. Predictors of early death in patients with acute pulmonary embolism. Am J Emerg Med. 2015;33:214-21.

8. Kayrak M, Erdogan HI, Solak Y, Akilli H, Gul EE, Yildirim O, et al. Prognostic value of neutrophil to lymphocyte ratio in patients with acute pulmonary embolism: a retrospective study. Heart Lung Circ. 2014;23:56-62.

9. Balta S, Demirkol S, Kucuk U. The platelet lymphocyte ratio may be useful inflammatory indicator in clinical practice. Hemodial Int. 2013;17:668-9.

10. Wang D, Yang JX, Cao DY, Wan XR, Feng FZ, Huang HF, et al. Preoperative neutrophil-lymphocyte and platelet-lymphocyte ratios as independent predictors of cervical stromal involvement in surgically treated endometrioid adenocarcinoma. Onco Targets Ther. 2013;6:211-6.

11. Torbicki A, Perrier A, Konstantinides S, Agnelli G, Galie N, Pruszczyk P, et al. Guidelines on the diagnosis and management of acute pulmonary embolism: the Task Force for the Diagnosis and Management of Acute Pulmonary Embolism of the European Society of Cardiology (ESC) Eur Heart J. 2008;29:2276-315.

12. Meyer G, Vicaut E, Danays T, Agnelli G, Becattini C, Beyer-Westendorf J, et al. Fibrinolysis for patients with intermediate-risk pulmonary embolism. N Engl J Med. 2014;370:1402-11.

13. Sharifi M, Bay C, Skrocki L, Rahimi F, Mehdipour M. Moderate pulmonary embolism treated with thrombolysis (from the "MOPETT" Trial) Am J Cardiol. 2013;111:273-7.

14. Konstantinides SV, Torbicki A, Agnelli G, Danchin N, Fitzmaurice D, Galie N, et al. ESC Committee for Practice Guidelines (CPG). Guidelines on the diagnosis and management of acute pulmonary embolism: the Task Force for the Diagnosis and Management of Acute Pulmonary Embolism of the European Society of Cardiology (ESC). Eur Heart J. 2014;35:3033-3069.

15. Goldhaber SZ, Visani L, De Rosa M. Acute pulmonary embolism: clinical outcomes in the International Cooperative Pulmonary Embolism Registry (ICOPER). Lancet. 1999;353:1386-1389.

16. Zahorec R. Ratio of neutrophil to lymphocyte counts--rapid and simple parameter of systemic inflammation and stress in critically ill. Bratisl Lek Listy. 2001;102:5-14.

17. Jo JY, Lee MY, Lee JW, Rho BH, Choi WI. Leukocytes and systemic inflammatory response syndrome as prognostic factors in pulmonary embolism patients. BMC Pulm Med. 2013;13:74. doi: 10.1186/1471-2466-13-74.
18. Falk E, Shah PK, Fuster V. Coronary plaque disruption. Circulation. 1995;92:657-671.

19. Hoffman M, Blum A, Baruch R, Kaplan E, Benjamin M. Leukocytes and coronary heart disease. Atherosclerosis. 2004;172:1-6.

20. Karataş $M B$, İpek $G$, Onuk T, Güngör B, Durmuş G, Çanga $Y$, et al. Assessment of prognostic value of neutrophil to lymphocyte ratio and platelet to lymphocyte ratio in patients with pulmonary embolism. Acta Cardiol Sin. 2016 May;32(3):313-320.

21. Ghaffari S, Nadiri M, Pourafkari L, Sepehrvand N, Movasagpoor A, Rahmatvand N, et al. The predictive value of total neutrophil count and neutrophillymphocyte ratio in predicting in-hospital mortality and complications after STEMI. J Cardiovasc Thorac Res. 2014;6:35-41.

22. Yildiz A, Yuksel M, Oylumlu M, Polat N, Akyuz A, Acet H, et al. The utility of the platelet-lymphocyte ratio for predicting no reflow in patients with ST-segment elevation myocardial infarction. Clin Appl Thromb Hemost. 2015; 21(3):223-228.

23. Kaya MG, Akpek M, Lam YY, Yarlioglues M, Celik T, Gunebakmaz O, et al. Prognostic value of neutrophil/lymphocyte ratio in patients with ST-elevated myocardial infarction undergoing primary coronary intervention: a prospective, multicenter study. Int J Cardiol. 2013;168:1154-9.

24. Soylu K, Yuksel S, Gulel O, Erbay AR, Meric M, Zengin H, et al. The relationship of coronary flow to neutrophil/lymphocyte ratio in patients undergoing primary percutaneous coronary intervention. J Thorac Dis. 2013;5:258-64.

25. Balta S, Unlu M, Arslan Z, Demirkol S. Neutrophil-to-lymphocyte ratio in prognosis of gastric cancer. J Gastric Cancer. 2013;13:196-7.

26. Kaya A, Kurt M, Tanboga IH. Neutrophil-to-lymphocyte ratio predicts contrast-induced nephropathy in patients undergoing primary percutaneous coronary intervention. Angiology. 2014;65:59.

27. Uthamalingam S, Patvardhan EA, Subramanian S, Ahmed W, Martin W, Daley M, et al. Utility of the neutrophil to lymphocyte ratio in predicting long-term outcomes in acute decompensated heart failure. Am J Cardiol. 2011;107:433-8.

28. Yildız A, Kaya H, Ertaş F, Oylumlu M, Bilik MZ, Yüksel M, et al. Association between neutrophil to lymphocyte ratio and pulmonary arterial hypertension. Turk Kardiyol Dern Ars. 2013;41:604-9.

29. Soylu K, Gedikli O, Ekși A, Avcloğlu Y, Soylu AI, Yüksel S,et al. Neutrophil-to-lymphocyte ratio fort he assessment of hospital mortality in patients with acute pulmonary embolism. Arch Med Sci 2016 Feb 1;12(1):95-100.

30. Ozcan Cetin EH, Cetin MS, Canpolat U, Akdi A, Aras D, Temizhan A, et al. Platelet-to-lymphocyte ratio as a novel marker of in-hospital and long-term adverse outcomes among patients with acute pulmonary embolism: a single-center large-scale study. Thromb Res 2017; 150: 33-40.

31. Kuo YT, Wang YY, Lin SY, Chang WD. Age and sex differences in the relationship between neutrophil-to-lymphocyte ratio and chronic kidney disease among an adult population in Taiwan. Clin Chim Acta. 2018 Nov;486:98-103.

32. engo V, Lensing AWA, Prins MH, Marchiori A, Davidson BL, Tiozzo F, et al. Incidence of chronic thromboembolic pulmonary hypertension after pulmonary embolism. N Engl J Med 2004;350:2257-64. 